\title{
Additional Value Through The Implementation of Blue Ocean Strategy In Gerabah Businesses In Takalar Regency
}

\author{
Anwar $^{1}$, A. Ratna Sari Dewi ${ }^{2}$ \\ ${ }^{1}$ Faculty of Economics, State University of Makassar, Indonesia \\ ${ }^{2}$ Faculty of Economics and Business, Hasanuddin University, Indonesia \\ \{anwar.rauf82@gmail.com\}
}

\begin{abstract}
The purpose of this research is to examine the added value of the gerabah business by implementing the Blue Ocean Strategy (BOS). The study used descriptive qualitative analysis based on four frameworks and six BOS principles. The results showed the implementation of BOS to create added value with the stages (1) eliminating rogue retailer networks; (2) Reducing less desirable production; (3) Improve retailer management, product quality control, and product design; (4) Creating social media (website) and conducting exhibition to exhibition in marketing channels. Then apply six principles, namely, (1) revising the market, design characteristics, quality and service flexibility, as well as adjusting trends in the imported gerabah business; (2) flexible business creativity; (3) Optimization of demand services; (4) Business operations with the criteria of utility for buyers, prices, costs, and adoption; (5) Changes in perspective on the owner of the pottery business; (6) Integrase strategy execution on an ongoing basis.
\end{abstract}

Keywords: Added Value, Blue Ocean Strategy

\section{Introduction}

The flow of globalization has become a trigger for competition in increasingly competitive small businesses. The growth of the small business sector during the last five years (2015-2019) reached an average of $10.89 \%$. This growth is an achievement in itself in the progress of small businesses, but the ability to grow into medium enterprises and even large enterprises is very small $(2.1 \%)$. This is a crucial problem for small businesses that cannot grow in the long term.

In particular, the problems faced by certain industries are internal problems regarding non-optimal manufacturing (starting from raw material supply, production capabilities, technological mastery and product competitiveness) and external problems regarding partisanship and public awareness of using domestic products (Ministry of Industry, 2019). This condition has an impact on the low productivity result and many small businesses have experienced business failures (Riyanti, 2003). This means that high performance of small businesses is an important necessity in survival, thus, the attention is needed in understanding how to improve the performance of small businesses in the economic market (Pribadi and Kanai, 2010). 
The leading small businesses in Takalar Regency have experienced relatively rapid growth during the last three years (2017-2019) in terms of the number of businesses and labor absorption, but did not make a significant contribution to the PDRB of Takalar Regency (BPS Takalar, 2019) This means that the economic growth in Takalar Regency is still not optimal and still needs improvement. This condition also illustrates that small businesses have not been able to provide maximum added value to the achievement of activities or regional economic performance. One of the leading commodity core industries in Takalar Regency is gerabah business.

The main problem for the gerabah business is that the level of technology used is still limited thus product creation is still limited, high market competition, market control by imported products also makes it more difficult to gerabah market. In terms of the strength of the gerabah business is the availability of sufficient raw materials and labor (BPS Takalar, 2019).

This condition is in line with Tambunan (2010) states that business development in small businesses in developing countries (NSB) is impeded by many obstacles. Common barriers include limited working capital and investment, difficulties in marketing, distribution and procurement of raw materials and other inputs, limited access to information on market and other opportunities, and technological capabilities. To overcome these problems, companies need a strategy in determining competitive advantages and determining ways to improve business performance.

According to the increasingly fierce competition in the gerabah industry, it requires business owners to implement appropriate strategic management in managing their business. Strategic management focuses on the integration of all organizational components for success. The integration that is meant is the involvement of all components which include everyone in the effort to have a sense of belonging, so that it is hoped that they will be able to make a positive contribution to the development and growth of the business. The strategic management process itself is a dynamic system, which requires continuous assessment and updating according to the environmental situation.

Selection of the right strategy and in accordance with the characteristics of the business is important for the gerabah business to take into account that the competition in the gerabah industry is getting tighter. A practical approach in achieving development and growth is the Blue Ocean Strategy (BOS) (Kim and Mauborgne, 2014). The BOS approach uses uncontested market space control. The market that is not contested is analogous to the "Blue Ocean" or blue zone which means business to compete independently without competitors. The main reason is that the gerabah business has always been in a market that is contested by many businesses in the gerabah industry which is analogous to the "Red Ocean" or red zone.

Based on value innovation, the BOS strategy challenges the gerabah business to break out of the competition by co-differentiating and lowering costs through a four-step framework (eliminate, create, improve and reduce). In addition, value equality and innovation are also carried out to provide benefits to consumers. BOS is oriented towards market growth and moves away from competition by taking advantage of strengths and opportunities while minimizing risks.

Value innovation in BOS is not just out of competition, but how to create value for consumers that cannot be obtained from competitors. To carry out value innovation, businesses must consider economic and profitable factors. This means that business actors must consider the innovation made at the expense of being economically feasible and able to generate longterm benefits. According to Kim and Mauborgne (1997a, b, c) that the focus on comparing (benchmarking) and winning the competition will lead to an imitative, not innovative approach 
to the market which often results in further price and commodity pressures. The business should make competition irrelevant by offering a leap in value to buyers. According to Hamel (1998) that success for old businesses in the industry depends on their ability to avoid competition and re-operate existing industrial models. This means that the recipe for success is not in taking the competition, but in taking a position that avoids competition. Ickis (2008) states that the implementation of BOS is not hampered by business size, business economies of scale, or must have a large market share, but companies are directed to achieve an optimal market niche and achieve strategic innovation that does not require large investment costs, but requires the creativity of entrepreneurs as business owners. The purpose of this research is to apply the Blue Ocean Strategy in increasing the competitiveness of the gerabah business. Specifically, the aim of this study is to implement BOS as an internal strategic orientation towards consumers based on the analysis of the four-step BOS framework.

\section{Method}

This research used descriptive research (descriptive research) which was exploratory in nature. This research emphasizes on presenting data, analyzing and interpreting data with the aim of systematically, factually, and accurately describing the facts and characteristics of the research object in accordance with the problems being studied, thus this research was conducted to identify environmental factors in the gerabah business, both internal and external, and to identify the implementation of strategic planning based on the Blue Ocean Strategy.

\section{Results}

The four-step framework was used to create a trade-off between low cost differentiation simultaneously and to create a new value curve in the gerabah business in Takalar Regency. In this case, there are four key questions to create a four-step framework, namely E-C-R-I

\section{Eliminate}

\section{What factors should be eliminated from the factors that the Industry has taken for granted?}

Oftentimes the competitive factors that have long been a competitive arena for companies in the pottery industry are taken for granted even though these factors have no value or even reduce value. What needs to be realized is that sometimes there is a fundamental change in what buyers value, but companies that focus on brenchmarking with competitors or with each other do not respond or even do not see these changes. One of the steps to eliminate is by cutting ties with rogue retailers. The retailer liaises entrepreneurs with consumers, but in this case the retailer does not sell and offer products to consumers so that the product cannot be recognized by the market.

\section{Create}

\section{What factors has not been offered by the industry that should be created?}

Nowadays, technology is a very important factor where digital use is vital in introducing products or services. Likewise, the gerabah entrepreneurs must follow technological developments. Currently what is being proclaimed by entrepreneurs is how to introduce and market their products easily and quickly. Previously, gerabah entrepreneurs marketed their products through traditional markets. By utilizing existing technology, gerabah entrepreneurs can now introduce and market their products outside the region or even abroad with an online 
store. Gerabah entrepreneurs can create social media or websites for their products so they can be accessed easily and quickly. Gerabah entrepreneurs also need to introduce and make consumers feel familiar with artificial pottery products from Takalar Regency which can be done with the Exhibition to Exhibition so that it will instill an image for consumers. By frequently holding exhibitions in and outside Takalar Regency, it is hoped that the product will be increasingly recognized by consumers and can increase income from the gerabah business.

\section{Reduce}

What factors should be reduced under industry?

The thing that needs to be reduced by entrepreneurs in Takalar Regency is product diversity. Entrepreneurs need to thoroughly review which products are most frequently ordered or in demand by consumers and which products are not ordered or frequently ordered by consumers. Products that are less desirable or often not ordered are reduced by the time they are made and the supply of raw materials or are even eliminated. This can help minimize costs incurred for labor costs and raw material costs by gerabah entrepreneurs in Takalar Regency. The labor and raw materials used to make products that are less desirable or that are often not ordered can also be diverted to make products that consumers are most ordered or interested in

\section{Increase}

\section{What factors should be increased above the industry?}

In the gerabah business in Takalar Regency, the things that need to be improved is retailer management, quality control, design and value added product. Maintaining relationships with retailers is very important. Business cooperation needs to be managed for the long term between retailers and pottery entrepreneurs. By establishing good cooperation, it can certainly help pottery products to be recognized by the market.

Gerabah entrepreneurs in Takalar Regency need to pay attention to the existence of quality control. Product quality standards made now may be different from those made before. The role of quality control is very large in assessing the feasibility of these products for sale where quality control starts from the selection of raw materials, the manufacturing process, and finished goods that are ready for sale.

Design is the first thing consumers see, so there is a need for innovation in products made by gerabah entrepreneurs in Takalar Regency. Ease of internet access can help gerabah entrepreneurs modify their products so that they can suit consumer tastes. Once quality control and design have become a concern, it allows for an increase in the added value of the product. This added value can make consumers more interested in gerabah products from Takalar Regency.

The four-step work (Eliminate-Create-Reduce-Increase) can be summarized in a fourstep working scheme such as table 1 below: 
Table 1. The Four-Step Work Scheme

\begin{tabular}{|c|c|}
\hline $\begin{array}{l}\text { Eliminate } \\
\begin{array}{l}\text { Relationships } \\
\text { rogue retailers }\end{array} \quad \text { with }\end{array}$ & $\begin{array}{l}\text { Create } \\
\begin{aligned} \text { - Creating social media } \\
\text { atau website } \\
\text { - Exibition to Exibition }\end{aligned}\end{array}$ \\
\hline $\begin{array}{l}\text { Reduce } \\
\quad-\quad \text { Product diversity }\end{array}$ & $\begin{aligned} & \text { Increase } \\
& \text { - } \text { Retailer management } \\
& \text { - } \text { Quality Control } \\
& \text { - } \text { Design } \\
& \text { - } \text { Value added product }\end{aligned}$ \\
\hline
\end{tabular}

The creation of a Blue Ocean Strategy in Gerabah Business in Takalar Regency through six principles, namely, (1) Market constraints in the gerabah industry on the side of the local government of Takalar Regency, especially Dharma Wanita, design characteristics, quality and service flexibility, as well as adjustment to imported gerabah business trends; (2) Focus on flexibility in business creativity; (3) Optimization of demand services; (4) implement the blue ocean strategy consistently based on the criteria of utility for buyers, price, cost, and adoption; (5) Overcoming business obstacles in strategy implementation through changing the perspective (mindset) of the gerabah business owner; (6) Integrate strategy execution on an ongoing basis.

\section{Discussion}

The results showed that the blue ocean strategy in the Gerabah Business can be applied through innovation in the four-step E-C-R-I work (eliminate-create-reduce-increase). The Gerabah Business must be able to gradually eliminate the impression of being low (low quality), so that it can compete in an increasingly competitive market. Eliminating relationships with retailers can be done easily in today's digital world by using direct marketing through Facebook, Twitter, Instagram, market places, blogs, YouTube and so on.

The main mistake that can arise in the gerabah entrepreneur is not focusing on the type of product, thus losing the identity of the product. Business owners still tend to diversify their products by looking at the business results of their competitors. Business owners should have confidence in the results to be competitive. Confidence must be driven by good relationships with partners, reliable product quality, distinctive designs, and product added value from the raw materials used.

The principle that must be carried out in implementing the blue ocean strategy in the Gerabah Business is to define consumers who are the target of the business, so that they can produce goods in accordance with business goals. Production that is carried out must try to move from mass production to production in accordance with the market. Market demand is the main reference in carrying out production. Pricing can be a control for the Gerabah Business owner which must be adjusted to the benefits provided, costs incurred and economic conditions. Gerabah Business owners must dare to break out of old habits to adapt to existing market developments, so that they can compete in the Gerabah Business on an ongoing basis.

\section{Conclusion}


The implementation of the Blue Ocean Strategy in Gerabah Business in Takalar Regency needs to apply the results of the Eliminate-Create-Reduce-Increase scheme, namely (1) Eliminating the factors associated with naughty retailers; (2) Reducing production factors for various kinds of products that are less desirable or often not ordered; (3) Increasing factors regarding retailer management, quality control of products, product design, and value added product factors; (4) Creating factors that can facilitate promotion and product sales by creating social media or websites and conducting exhibition to exhibition.

Then carry out six principles for implementing the Blue Ocean Strategy, namely, (1) Market constraints in the gerabah industry on the side of the local government of Takalar Regency, especially Dharma Wanita, design characteristics, quality and service flexibility, as well as adjustment to imported gerabah business trends; (2) Focus on flexibility in business creativity; (3) Optimization of demand services; (4) implement the blue ocean strategy consistently based on the criteria of utility for buyers, price, cost, and adoption; (5) Overcoming business obstacles in strategy implementation through changing the perspective (mindset) of the gerabah business owner; (6) Integrate strategy execution on an ongoing basis.

\section{References}

BPS, (2019). Kabupaten Takalar dalam Angka. BPS Kabupaten Takalar

Hamel, Gary. (1998). Opinion: Strategy Innovation and The Quest for Value. MIT Sloan Management Review 39, no. 2, 8.

Ickis. (2008). The Blue Ocean Strategy. Cotrugli Business School, annual report.

Kementerian Perindustrian, R. I. (2019). Analisis Perkembangan Industri.

Kim, W. Chan dan Renee Moubourgne. (2014). Blue Ocean Strategy. Jakarta: PT. Serambi Ilmu Semesta

Kim, W. Chan, and Renee Mauborgne. (1997a). Value Innovation: The Strategic Logic of High Growth, Harvard Business Review 75, Januari - Februari Edition. 102-112.

Kim, W. Chan, and Renee Mauborgne. (1997b). On The Inside Tracks, Financial Times, 7 April.

Kim, W. Chan, and Renee Mauborgne. (1997c). When Comvetitive Advantage is Neither. Wall Street Journal, 21 April.

Pribadi, H., \& Kanai, K. (2011). Examining and exploring Indonesia small and medium enterprise performance: An empirical study. Asian Journal of Business Management, 3(2), 98-107.

Riyanti, B. P. D. (2003). Kewirausahaan dari sudut pandang psikologi kepribadian. Jakarta: Grasindo. 
Tambunan, T. (2010, April). Apakah Kebijakan Pengembangan Usaha Kecil dan Menengah di Indonesia Selama Ini Efektif. In Makalah Workshop. BPPT (Vol. 8). 